\title{
Why, what, who, when and how? Hand hygiene measured in India?
}

\author{
J Hemalatha*, D Sureshkumar \\ From 3rd International Conference on Prevention and Infection Control (ICPIC 2015) \\ Geneva, Switzerland. 16-19 June 2015
}

\section{Introduction}

Hand hygiene $(\mathrm{HH})$ is the single most important factor in the prevention of health care-acquired infections. Comprehensive monitoring of hand hygiene compliance is considered integral parts of a successful hospital infection control program. However, measuring adherence to hand hygiene guidelines is resource intensive and complicated by lack of standardized methodology.

\section{Objectives}

Our aim was to survey the methodologies used to measure hand hygiene guidelines across different Indian hospitals.

\section{Methods}

The survey was conducted in person among infection control professionals working in different Indian hospitals (one per institution) using questionnaire developed based on WHO hand hygiene guidelines during their participation in international infection control conference held in India during the month of March 2015.

\section{Results}

Infection control professionals representing 26 Indian hospitals (different types) participated in the survey. In India $\mathrm{HH}$ was measured mainly due to quality imitative $(11 / 2642.30 \%)$ or part of accreditation (10/26 $-38.46 \%)$ requirement. The ICPs monitor $\mathrm{HH}$ majority of the time (24/26 92.30\%), they focus mainly on monitoring adherence to $5 \mathrm{HH}$ moments $(15 / 26-57.69 \%)$ and monitor during the day time (22/26 -84.61\%). Once in a month (12/26-46.15\%) and direct observation $22 / 26(84.61 \%)$ was the preferred mode of monitoring in India.

Infectious Disease Education \& Reserach Foundation, Chennai, India

\section{Conclusion}

Majority of Indian hospitals monitor compliance to $\mathrm{HH}$ guidelines, however comprehensive monitoring of all aspects of $\mathrm{HH}$ was missing in many of the hospitals. Clearly, further research to develop efficient, reliable, and comprehensive methods for monitoring hand hygiene compliance is urgently required in India.

\section{Disclosure of interest}

None declared.

Published: 16 June 2015

\section{doi:10.1186/2047-2994-4-S1-P297}

Cite this article as: Hemalatha and Sureshkumar: Why, what, who, when and how? Hand hygiene measured in India? Antimicrobial Resistance and Infection Control 2015 4(Suppl 1):P297.

\section{Submit your next manuscript to BioMed Central and take full advantage of: \\ - Convenient online submission \\ - Thorough peer review \\ - No space constraints or color figure charges \\ - Immediate publication on acceptance \\ - Inclusion in PubMed, CAS, Scopus and Google Scholar \\ - Research which is freely available for redistribution

